\title{
Mixing It: Diversity in World War Two Britain
}

Review Number: 2305

Publish date: Thursday, 14 February, 2019

Author: Wendy Webster

ISBN: 9780198735762

Date of Publication: 2018

Price: $£ 25.00$

Pages: 336pp.

Publisher: Oxford University Press

Publisher url: https://global.oup.com/academic/product/mixing-it-9780198735762?cc=gb\&lang=en\& Place of Publication: Oxford

Reviewer: Henry Irving

There are few historical events with a cultural legacy as enduring as that connected to the Second World War. The conflict occupies an important place within many personal, as well as national, narratives. Those interested in its history and heritage are confronted by an enormous range of writing, on a wide variety of themes. The problem, according to Jan Black, a 94-year-old RAF veteran quoted on the first page of Wendy Webster's Mixing It: Diversity in World War Two Britain, is that 'people just don't know their history' (p. 3).

Black, who was born Jan Stangryczuk in eastern Poland, volunteered to join the British war effort in 1940. He travelled to Britain via Buenos Aires and Belfast, joined the RAF, and trained as an air gunner in Blackpool. His globe-crossing story is similar to many of those contained within Mixing It. The book deliberately challenges popular assumptions about the British home front by showing that it was inhabited by people drawn from across the world. These arrivals included allies like Jan Black, but also war-workers, refugees, nurses, exiles, prisoners of war, and neutral observers. Their existence, argues Webster, made Britain more diverse than at any time in its past (p. 2).

Mixing It presents a history of multinational and multi-ethnic Britain during the Second World War, considering the experiences of those who arrived in Britain and the (often contradictory) responses to them (p. 16). It is an ambitious book that combines an analysis of government policy with social and cultural history. With the exception of a chapter on '1940' - which considers the British evacuation from Dunkirk, the arrival of refugees, and the internment of enemy aliens - and another on the 'Aftermath', the book is arranged thematically; there are chapters on the experience of allies, enemies, imperial subjects, the English language, and the 'Sexual patriotism' of British women. The book is the first study to consider these inherently complex subjects as part of what Webster describes as the 'big proposition': that is, the large scale population movements that took place during a truly global war (p. 21).

Webster approaches this task by seeking to balance the big picture with intimate detail. She starts each chapter with an individual story and uses a rich tapestry of personal narrative to illustrate her themes. The individual stories are as diverse as their protagonists: some found Britain welcoming, whereas others felt longed to return home. Their accounts are, however, united by their poignancy and Webster's skilful prose. The reader is introduced to Porokuru Pohe, a Maori pilot executed after taking part in the 'great escape', 
Mary Mulry, an Irish nurse who treated British and French troops evacuated from Dunkirk, and Rudolph Dunbar, a Guyanese musician and journalist who was lauded by British propagandists. These biographical sketches give Mixing It an emotional resonance that is too often lost in academic writing.

The use of these individual stories is best understood in relation to the wider project of which this book is part. As Webster notes, Mixing It was conceived alongside a display at Imperial War Museum North. The display - Mixing It: The Changing Face of Wartime Britain - was based on oral history interviews, outreach work with family historians, and archival research. Webster explains that each story was based on research using autobiographies, biographies, diaries, and letters. In the book, these narratives have been combined with Mass Observation surveys to provide insight into public opinion and a range of official sources, including Home Intelligence reports, postal censorship records, and government memoranda. She concedes that the personal narratives may not be representative of wider groups, but argues that they offer insight into a range of experiences, hopes, and anxieties (p. 21).

Although Mixing It puts the exhibition's stories into a more academic form, they have not lost their emotional power. Consider the example of Sergeant Arthur Walrond, whose story is told at the beginning of the chapter on 'Sexual Patriotism'. Walrond was a Barbadian air gunner who was violently assaulted by two American soldiers for approaching a young woman at a dance at Bury St Edmonds. Incensed by the 'ugly evils of discrimination and prejudice', he lodged an official complaint about this incident on 29 June 1943. That night, Webster tells us, he was killed in action. When the case was pursued by a Miss P.G. Palmer, who Webster suggests was the woman at the dance, it emerged that Waldron's complaint had been shelved by his commanding officer. Just four months after the assault, military authorities concluded that it was too late to pursue the matter (pp. 197-8).

Webster uses this case to illustrate complex attitudes towards colour bars during the war. She explains that white Britons may not have recognised Waldron's description of racial prejudice, as official and unofficial propaganda sought to demonstrate Britain as a tolerant nation. Webster claims that this was reflected in popular opinion, which embraced the idea 'Fit to fight, fit to mix'. She cites as evidence the example of a Warrington dancehall owner, who provoked an American boycott after refusing to enforce a colour bar. She also highlights favourable comments about black GIs compared to their apparently brash, white counterparts. However, Webster demonstrates that there were limits to British tolerance, especially when mixing extended beyond 'friendly but brief' encounters. Although inter-racial marriage was legal in the United Kingdom, she shows that concerns about mixed-race children extended to the highest echelons of government and argues that racialist patriotism easily trumped liberalism when it came to sex (p. 215).

This argument is one of many developed within the book. By approaching the Second World War from the perspective of diversity, Webster demonstrates how it is possible to cut across various established historiographies. Whereas the chapter on 'Sexual patriotism' invokes the women's and gender histories of the war, others are more concerned with the experience of combatants and non-combatants, the history of the British Empire, media history, and cultural memory. The substance of each chapter ranges even more widely and readers will find reference to many aspects of life on the home front. Thanks to this scope, Mixing It is as useful an introduction to the Second World War as established texts like Angus Calder's The People's War.(1) It is a wonderful example of a book that provides fresh insight by shifting the point of focus. 
A clear example of this can be seen in the chapter 'The Empire comes to Britain'. This is the most closelyrelated to Webster's existing work on Englishness and the Empire, 1939-1965 (2) and uses some of the same evidence. However, while her earlier work considers how British policy-makers grappled to integrate the Empire into a wartime narrative that emphasised 'the People's War', this chapter focuses on the experience of those who were said to demonstrate 'the People's Empire'. Building on the example of the Ministry of Information film West Indies Calling, which is analysed in both books, Webster shows that there were practical limits to the idea that the Empire was a multi-racial community. It is said that the message was more commonly made overseas than on the home front and was articulated in such a way that limited it to the war effort. The objective, Webster suggests, was to stress unity rather than highlight diversity (p. 117).

While its distinct perspective makes Mixing It a thought-provoking read, those who specialise in the Second World War may find Webster's treatment of its historiography slightly frustrating. The book makes occasional reference to existing works, but these exist solely to point out that other research has been done. For instance, when considering Italian prisoners of war, Webster tells us that 'Bob Moore argues that government policy turned them from liabilities into assets, working in essential industries where there were labour shortages' (p. 77). This technique is used to highlight subjective evidence throughout the text. Elsewhere in the same chapter, for example, the reader is told that some groups 'have been consigned to what Wendy Ugolini ... calls a "commemorative no man's land"' (p. 71). The reader is left to make their own connections with Webster's arguments.

There are similar absences where sources are concerned. Webster does reflect on the strengths and weaknesses of her material in the introduction, but this area is surprisingly under-developed. In stark contrast to her first monograph, Imagining Home (3), almost nothing is said about the use of oral history, nor the way that films and radio broadcasts have been selected for analysis. Important points about documentary records are also overlooked, for example the fact that Mass Observation worked on behalf of the Ministry of Information between 1940 and 1941 or that early Home Intelligence reports were based on material submitted by those responsible for carrying out propaganda at a local level. This is not to question the validity of such material: the sources used provide the best available insights into popular opinion during the war. Rather, it is to suggest that their use could be explained more convincingly without compromising the book's accessibility.

The relative lack of methodological and historiographical engagement is exacerbated by the decision not to include a formal conclusion. This absence is particularly notable because of the impact that Mixing It should have on our collective understanding of the Second World War. Although it is not explicitly acknowledged, Webster has made a significant contribution to debates about the 'People's War', especially those relating to the experiences of minority groups, women, and the role of propaganda. She has also convincingly argued that these debates should be considered using a transnational frame of reference. In doing so, Webster has drawn attention to various possibilities for further research and I am convinced that Mixing It will encourage others to follow her lead.

Any frustration must also be tempered by the knowledge that Mixing It is a substantial piece of public history. The book is readable and, as Paul Addison says in the publisher's blurb, is both 'a first class scholarly history and a parable for our own day'. Webster does make frequent allusions to contemporary British attitudes. In the chapter 'Language, speech, sound', for example, she quotes the following response to a Mass Observer: 'I can't fancy the streets all full of foreigners, and all jabbering away the way they do makes you feel it isn't old London sometimes, it sounds like some foreign place' (p. 177). She also considers the way that the war's diverse history has been remembered (and forgotten) since 1945, pointing out that a former-servicemen who returned to Britain on the SS Empire Windrush believed Britain had already become a less tolerant place (p. 239).

Such links are explored most explicitly in Webster's chapter on the 'Aftermath'. This describes a hardening of attitudes after 1945, coupled with increased fears about migration and a growing mythology that Britain 
'fought alone' after the Fall of France. Alluding back to the example of Jan Black, Webster pays particular attention to the fate of Poles. She explains that many Poles, especially those who had fled eastern Poland after the Soviet invasion in 1939, felt betrayed by the Yalta agreement. This feeling was exacerbated when the Attlee government initially refused to guarantee settlement in Britain, despite an earlier promise by Winston Churchill that Poles who had fought under the British flag should be given citizenship (pp. 236-7). Webster tells us that an opinion poll conducted in June 1946 found that 56 per cent of Britons did not agree that Poles should have the right to stay in Britain (p. 242), while graffiti bearing the words 'Poles go home' was recorded near Polish air bases (p. 19).

It is clear that Webster believes that many more people should be aware of this history. She explains in the introduction that these examples were included in the display at Imperial War Museum North and quotes a museum visitor, who believed it was a "sad reflection on "Brexit Britain". Continuing on this theme, Webster reminds readers that a Polish Cultural Centre in London was vandalised with xenophobic graffiti days after the United Kingdom's vote to leave the European Union in June 2016. Mixing It makes a determined attempt to historicise such attitudes. Carefully avoiding simplistic conclusions, Webster shows that Second World War Britain was neither tolerant nor racist. Instead, she demonstrates that it played stage to a variety of often conflicting views about race, nationality, and belonging. It is a compelling argument, built upon a rich collection of sources; it deserves to be widely read.

\section{Notes}

1. Angus Calder, The People's War (London, 1969).Back to (1)

2. Wendy Webster, Englishness and the Empire, 1939-1965 (Oxford, 2005). Back to (2)

3. Wendy Webster, Imagining Home (London, 1998). Back to (3)

\section{Other reviews:}

Guardian

https://www.theguardian.com/books/2018/may/18/mixing-it-wendy-webster-review [2]

Times Higher Education

https://www.timeshighereducation.com/books/review-mixing-it-diversity-in-world-war-two-britain-wendywebster-oxford-university-press [3]

Source URL:https://reviews.history.ac.uk/review/2305

\section{Links}

[1] https://reviews.history.ac.uk/item/298722 [2] https://www.theguardian.com/books/2018/may/18/mixingit-wendy-webster-review [3] https://www.timeshighereducation.com/books/review-mixing-it-diversity-inworld-war-two-britain-wendy-webster-oxford-university-press 